\title{
Forord til »værdiformsanalytisk rekonstruktion«
}

\author{
Knud Pedersen og Thomas Stenderup
}

I den strøm af engelsksproget litteratur om Marx' kapitalanalyse og specielt om Marx' værditeori, som er fremkommet i de seneste år ${ }^{1}$, er det foreliggende arbejde bemærkelsesværdigt derved, at det har rødder tilbage i den Vesttyske 'rekonstruktionsmarxisme', som også havde en kort glansperiode på de danske universiteter i 70erne. Artiklen udgør første del af Sydney-Konstanzgruppens (S-K) ambitiøse rekonstruktionsprojekt, som udover Marx' Kapitalanalyse omfatter analyse af konkurrence, stat, privatsfære, kultur, ideologi og kritisk videnskab².

Titlen på nærværende artikel er egentlig misvisende fsv. man forventer et overvejende filologisk studium af den 'autentiske' Marx. Mens 70ernes rekonstruktionsmarxisme havde et betydeligt filologisk islæt og i det hele taget sigtede på en blotlæggelse af indholdet i Marx' hovedværker, er ambitionsniveauet i S-K's projekt mere omfattende. Den indsigt, som blev oparbejdet i forbindelse med rekonstruktionsmarxismen, danner baggrund for intentionerne om en totalitetsteori for det borgerlige samfund. I udarbejdelsen af en sådan udgør Kapitalanalysen et vigtigt råmateriale, men den marxske analyses ufærdige, nærmest fragmentariske karakter - tillige med Marx' »metodologiske usikkerhed « (Backhaus) - nødvendigg ør iflg. forfatterne en betydelig reformulering af Kapitalanalysen som grundlag for en systematisk teori om den borgerlige samfundsform.

Foregribende indvendinger mod de temmelig markante afvigelser fra Marx, som præsenteres i nærværende og følgende artikler, hedder det på paroleform hos S-K: »I rekonstruktionsarbejdet - og med nødvendighed i udbygningsarbejdet - kan det ikke være et spørgsmål om sidestilling af Marx-citater eller blot gengivelse af Marx' argumentation, men om at udvikle en autonom tænkning, som - omend den i nogen grad trækker på Marx - må vurderes på egne fortjenester $\aleph^{3}$.

1. Udover de bøger og artikler, som er nævnt i artiklens note 1, kan nævnes: M. Lippi Value and Naturalism in Marx, London 1979. M. de Vroey »On the obsolescence of the Marxian Theory of Value: A Critical Review « in Capital \& Class 17, 1982.

Også det amerikanske tidsskrift Review of Radical political Economics har taget værdidiskussionen op i temanummeret 'Modern Approaches to the Theory of Value' URIE, vol 14 no 2; 1982.

2. Kurasje planlægger foreløbig at publicere 3 yderligere artikler, som sammen med den foreliggende udgør kapitalanalysedelen af S-K projektet.

3. M. Eldred »Critique of competetive Freedom and the State« p. 6. 
I deres intentioner om en totalitetsteori for det borgerlige samfund afgrænser S-K sig samtidig fra marxismetraditioner, som i Marx' hovedværker ser grundlaget for en historie- eller udviklingsteori ('Histomater'); dvs. både fra en teori om den progressive udvikling af klassesamfund (traditionel historisk materialisme) $o g$ fra en teori om udviklingen indenfor det borgerlige samfunds epoke, dvs. analysen af såkaldte objektive $\emptyset$ konomiske eller andre 'bevægelseslove'. Heroverfor opstiller S-K programmet om én for hele det borgerlige samfunds epoke gyldig analyse af dette samfunds sociale relationers almene form.

Kodeordet i S-K's reformulering er formanalyse; en tilgang som jo ikke er ny ${ }^{4}$, men som i S-K's udgave undergår en betydelig udvikling.

Både ældre og nyere fors $\emptyset \mathrm{g}$ på at udsondre de formanalytiske elementer hos Marx fremhæver ofte formanalysen som grundlaget for visse »kvalitative« aspekter i Marx' værditeori, hvorigennem denne kan adskilles fra specielt Ricardos ditto. Marx skulle således have udbygget Ricardos kvantitative arbejdsværdilære ved at tilføre værdibestemmelserne et »kvalitativt « indhold gennem undersøgelsen af vardiformen, og herigennem have besvaret det kritiske spørgsmål »hvorfor arbejdet ... giver sig udtryk $\mathrm{i}$ arbejdsproduktets værdi« (Rh1, 181 mod. $)^{5}$.

Efter denne opfattelse skulle det formanalytiske element altså være dét, som adskiller Marx fra sine klassiske forgængere (og neoricardianske efterfølgere), og som muligg ør en overskridelse af den rent kvantitative, historieløse betragtning hos disse. Senest har imidlertid Backhaus' arbejder peget på, at de formanalytiske elementer i Marx' værditeori er alt andet end klare både hos Marx selv og hos hans fortolkere. Marx var iflg. Backhaus »metodologisk usikker«, hvilket bl.a. kom til udtryk i en stadig 'degenerering' af værditeorien i de successive fremstillinger, som Marx udarbejdede. I følge Backhaus kan den værdiformsanalytisk fortolkede værditeoris problem dog identificeres som et pengeproblem, hvorved værditeorien som pengeteori præsenterer sig som en kritik af pramonetar varditeori, herunder Ricardos arbejdsværdilære ${ }^{6}$.

4. Den formanalytiske læsning af Kapitalen kan formentlig føres tilbage til F. Petry »Der soziale Gehalt der Marxschen Werttheorie« (1916) og Rubins »Essays on Marx' theory of value « (1929). En række nyere bidrag kunne nævnes, men de har stort set alle samme svaghed (dvs. 'Marx-loyalitet') som ovennævnte, jvf. nedenfor.

5. Dette synes at være Marx’ selvforståelse: Marx karakteristiske kommentarer til Ricardos fremstilling er, at den er »mangelfuld « (T 2, 196). Ricardo »focuserer ensidigt på værdistørrelsen« $(\mathrm{T} 3$, 154). Ricardo har »forsømt $\ll$ at undersøge formen $(\mathrm{T} 3,154)$. »Den kvalitative side af sagen $\ll$ er ikke udviklet hos Ricardo (T 3, 156). Etc.

6. Se Backhaus »Om forholdet mellem det 'logiske' og det 'historiske' i Marx' kritik af den politiske $\emptyset$ konomi « in Kurasje 27/28. 
S-K tager denne tråd op, idet de påviser, at den som pengeteori konsekvent udarbejdede værdiformsanalyse er uforenelig med de arbejdsværditeoretiske elementer hos Marx: Værdiformsanalysen peger på det samfundsmæssige arbejdes aposterioriske karakter og udelukker derigennem enhver (herunder også en arbejdsværditeoretisk) apriorisk bestemmelse af værdien.

Opgivelsen af arbejdsværditeorien får selvsagt betydelige konsekvenser for den resterende kapitalanalyse, ligesom de traditionelle værditeoriproblemer (reduktionsproblemet, transformationsproblemet etc.) stiller sig i nyt lys, hvis ikke de endegyldigt aflives. Dette skal dog ikke berøres nærmere her.

Hvor Backhaus' arbejder har kastet nyt lys over Marx' »metodologiske usikkerhed « og herigennem på indholdet i problematikken vedrørende forholdet mellem logik og historie, forekommer S-K-projektet, som i høj grad er inspireret af Backhaus, at være et vigtigt bidrag til udviklingen af en formanalytisk kapitalismeanalyse. Gennem afvisningen af den strengt logiske immanente deduktion af begreber og gennem udfoldelsen af den Glaser-inspirerede 'dialogdialektik' ${ }^{7}$, hvor begreberne udvikles $i$ et stadigt 'samspil' mellem den umiddelbare erfaring/bevidsthed og reflektionen heraf, forekommer det, at S-K har fået tilført formanalysen et indhold, der gør det muligt at tale om en »udlæsningsstrategi« som metodologisk alternativ til traditionel samfundsvidenskab. Backhaus' 'naive' spørgsmål om, hvorvidt det »lader sig afgøre, om en bestemt struktur er blevet 'lasstud' af et bestemt fænomen eller omvendt er blevet last ind i det? $\ll^{8}$ er jo ikke mere naivt end det er afslørende for den kendsgerning, at marxistiske traditioner frem til idag har haft samme 'empiritroskabsproblemer' som de, den traditionelle samfundsvidenskab er blevet tillagt. S-K-projektet gør ikke krav på at have løst ethvert metodologisk og teoretisk-indholdsmæssigt problem for en totalitetsteori om det borgerlige samfund. Men det peger i en bestemt retning for at frugtbargøre de idag så udskældte filologiske kapitalrekonstruktionsstudier.

Oversættelsen af den engelske tekst har voldt visse vanskeligheder. Dels er der ikke rigtig nogen tradition for oversættelse af engelske tekster indenfor genren, dels har den Hegel-inspirerede metodologi, som S-K trækker på, ingen særlig tradition herhjemme, og endelig nødvendigg $\varnothing r$

7. Se note 2 i artiklen nedenfor.

8. Backhaus op.cit. p. 164. 
S-K's reformulering af centrale marxske begreber brug af termer, der markerer en afvigelse fra de gængse marxske. Disse forhold har resulteret $\mathrm{i}$, at vi i oversættelsen har anvendt visse termer/konstruktioner, som kan virke noget uvante, men som på den anden side skulle markere ét af ovennævite forhold.

\section{Forkortelser}

\section{Marx}

Rh 1, Rh 2, Rh 3: Kapitalen, bd. I, II og III Kbh. 1970.

K1, K2, K3: Das Kapital, bd. I, II og III in Marx-Engels Werke Berlin, bd. 23, 24 og 25.

Btk: Bidrag til kritikken af den politiske фkonomi Kbh. 1974.

Z: Zur Kritik der Politischen Ökonomie in MEW 13

Gr: Grundrids til kritikken af den politiske фkonomi Århus 1977.

G: Grundrisse der Kritik der politischen Ökonomie (Rohentwurf) 1857-58, Berlin DDR 1953.

T1, T2, T3: Teorier om mervardien bd. I II og III Kbh. 1979.

TM1, TM2, TM3: Theorien über den Mehrwert Bd. 26.1, 26.2 og 26.3 MEW.

B: Briefe über das 'Kapital' Berlin DDR 1954.

\section{Andre}

DgV: Roth/Kleiber/Hanlon/Eldred,

Die gedoppelte Verdopplung. Zum Ausbau des Marxschen Systemfragments; udkommer.

RVfA: Eldred/Hanlon, 'Reconstructing Value-form Analysis' in Capital \& Class nr. 13 1981.

VRAK 1-4 (RVfA 1-4): Værdiformsanalytisk rekonstruktion af Kapitalen, del 1-4. Publiceres i Kurasje.

CCF\&S: Eldred, Critique of Competitive Freedom and the State: Outline of an Extension to Marx's Uncompleted System'; upubliceret 1981. 